\author{
Michat Żemta \\ Uniwersytet Pedagogiczny w Krakowie, Polska - Pedagogical University of Krakow, Poland \\ RAFAt WORONKOWICZ \\ Uniwersytet Pedagogiczny w Krakowie, Polska - Pedagogical University of Krakow, Poland
}

\title{
Znaczenie stereotypów w postrzeganiu atrakcyjności Nowej Huty dla odwiedzających i mieszkańców
}

\section{Significance of stereotypes in the perception of attractiveness of Nowa Huta (Poland) for visitors and citizens}

Streszczenie: Artykuł dotyczy szeroko pojętej tematyki percepcji i postrzegania przestrzeni turystycznej. Celem badawczym było przedstawienie powyższych zagadnień $\mathrm{w}$ odniesieniu do najmłodszej dzielnicy Krakowa - Nowej Huty. Materiał empiryczny pracy stanowią wyniki badań ankietowych przeprowadzonych w grupie 400 mieszkańców stałych i tymczasowych Krakowa i najbliższych okolic. Główna hipoteza badawcza odnosi się do występowania różnic w percepcji i postrzeganiu Nowej Huty w zależności od miejsca stałego zamieszkania ankietowanych. W wyniku analizy zgromadzonego materiału stwierdzono, że dzielnica ta jest znana większości respondentów. W opinii ankietowanych Nowa Huta jawi się jako dzielnica szara, niebezpieczna i budząca strach. Pozytywne postrzeganie dzielnicy jest charakterystyczne głównie dla jej stałych mieszkańców. Wyniki badań mogą być wykorzystane w określeniu kierunku, w którym powinna rozwijać się dzielnica, aby wzbogacić swój wizerunek i stać się bardziej atrakcyjną turystycznie. Wyniki badań potwierdzają też, że dla kształtowania pozytywnego wizerunku miejsca ważna jest jego znajomość.

\begin{abstract}
The paper undertakes the broadly understood perception of tourism space. The research aim is to present the topic in the context of Nowa Huta - the youngest quarter of Krakow (Poland). Empirical data was gathered on the basis of questionnaires distributed among 400 permanent and temporal residents of Krakow and the closest neighbourhood of the city. The main hypothesis is related to the existence of differences in the perception of Nowa Huta according to the place of residence of respondents. On the basis of analysis of the empirical material it was proved that the majority of respondents are familiar with the quarter. In their opinion, Nowa Huta is presented as a dangerous, grey, and scary place. Positive perception of the quarter is typical mainly its residents. The results might be used to determine the directions of the future development of Nowa Huta to improve its image and become more attractive for tourists and residents. The results also prove the relationship between the familiarity of the place and its positive perception.
\end{abstract}

Słowa kluczowe: destynacja; Kraków; Nowa Huta; percepcja; wizerunek

Keywords: destination; image; Krakow; Nowa Huta; perception 
Otrzymano: 21 października 2020

Received: 21 October 2020

Zaakceptowano: 3 czerwca 2021

Accepted: 3 June 2021

\section{Sugerowana cytacja/Suggested citation:}

Żemła, M., Woronkiewicz, R. (2021). Znaczenie stereotypów w postrzeganiu atrakcyjności Nowej Huty dla odwiedzających i mieszkańców. Przedsiębiorczość - Edukacja [Entrepreneurship Education], 17(2), 92-104. doi: https//doi.org/10.24917/20833296.172.7

\section{Wstęp}

Współczesny rynek turystyczny jest rynkiem o bardzo wysokim poziomie konkurencji, na którym rywalizują, w sposób podobny do przedsiębiorstw, także różne miejsca (destynacje, obszary recepcji turystycznej, ang. tourism destinations), aktywnie dążące do przyciągnięcia jak największej liczby odwiedzających. Specyfika rynku sprawia, że jednym $\mathrm{z}$ najistotniejszych narzędzi w działalności marketingowej poszczególnych destynacji jest kształtowanie marki i wizerunku miejsca. Według J.L. Cromptona (1979), wizerunek miejsca jest sumą przekonań, wrażeń, myśli, wyobrażeń i emocji jednostki bądź grupy osób. Jest to twór bardzo złożony, zmienny w czasie i subiektywny. Jest konglomeratem złożonym z uczuć, sądów, opinii, postaw i faktów (Szromnik, 2015).

W takim konglomeracie elementów racjonalnych i nieracjonalnych ogromną rolę mogą odgrywać mniej lub bardziej zakorzenione stereotypy. Często stereotypowe postrzeganie poszczególnych miejsc polega na przypisywaniu im cech negatywnych. Walka z tym jest zadaniem szczególnie trudnym dla marketerów, gdyż weryfikacja stereotypów poprzez konfrontację z rzeczywistością nie jest możliwa. Potencjalni turyści są zniechęcani do odwiedzenia danego miejsca przez stereotypowe jego postrzeganie, nie mają więc szansy na weryfikację swojej percepcji. Przykładem obszaru obarczonego stereotypowym postrzeganiem jest dzielnica Krakowa - Nowa Huta. W jej przypadku z jednej strony wskazać można przykłady udanych projektów odwołujących się do typowych skojarzeń tej dzielnicy z czasami PRL-u, z drugiej strony skojarzenia te dla wielu potencjalnych odwiedzających stanowić mogą istotny czynnik zniechęcający. Jednym z ważnych elementów mogących wspomóc przełamanie stereotypowego postrzegania Nowej Huty jest jej percepcja przez mieszkańców Krakowa, gdyż przyjmuje się, że to właśnie mieszkańcy są jednym z najważniejszych „nośników” pozytywnego lub negatywnego postrzegania poszczególnych miejsc. Dlatego celem prezentowanych badań była analiza percepcji Nowej Huty przez osoby mieszkające w Krakowie i najbliższych okolicach na stałe lub tymczasowo. Badania przeprowadzono na grupie 400 osób w listopadzie 2019 roku.

\section{Wizerunek i stereotypy w turystyce}

Współczesna konkurencja na rynku turystycznym rozgrywa się przede wszystkim pomiędzy poszczególnymi destynacjami (Go, Govers, 2000: 79). W praktyce oznacza to, że działania zmierzające do przyciągnięcia turystów prowadzone na własną rękę przez pojedynczego usługodawcę w danym miejscu docelowym skazane są na niepowodzenie, jeśli potencjalny klient będzie postrzegał owo miejsce jako niewarte odwiedzenia. Szczególnym „dobrem wspólnym” wszystkich podmiotów zaangażowanych w proces obsługi turysty 
jest więc wizerunek tego miejsca, gdyż to on przesądza o wyborach dokonywanych przez potencjalnych odwiedzających. Według A. Szromnik, wizerunek ,jest szczególną pozycją zasobów udostępnianych przez region miejscowym firmom. [...] Jako szczególna wartość rynkowa wykorzystywany jest on nieodpłatnie, bez większych ograniczeń ze względu na niewyczerpywalność tej pozycji aktywów regionalnych" (Szromnik, 2007: 154).

Zatem sukces poszczególnych usługodawców w danym miejscu jest ze sobą powiązany skomplikowaną siecią zależności i wzajemna konkurencja między nimi, w wielu sytuacjach istotna dla powodzenia, nie może całkowicie przesłonić konieczności współpracy dla kreowania pozytywnego wizerunku i doskonalenia jakości produktu całego miejsca docelowego. Obok postrzegania swojej oferty jako odrębnego produktu oferowanego na rynku turystycznym poszczególni usługodawcy muszą również potrafić spojrzeć na produkt turystyczny oczami nabywcy, który postrzega go jako złożone przeżycie od momentu opuszczenia domu do momentu powrotu (Smith, 1994: 586). Doświadczenie turysty jest zatem wiązane z pobytem w określonym miejscu, a usługi przedsiębiorstw turystycznych (touroperatorów, przewoźników, hotelarzy) są postrzegane bardziej jako sposób realizacji głównej korzyści, którą jest pobyt, niż jako ta korzyść (Żemła, 2003: 23).

Wizerunek destynacji turystycznych jest przedmiotem intensywnych badań naukowych od wielu lat i obecnie można wskazać przykłady prac w przekonujący sposób porządkujących współczesną wiedzę na ten temat (Afshardoost, Eshaghi, 2020; Li, Ali, Kim, 2015; Souiden, Ladhari, Chiadmi, 2017). Pojęcie to czerpie podstawy teoretyczne z licznych szerszych koncepcji marketingowych, takich jak wizerunek firm czy wizerunek miast i regionów. Należy jednak pamiętać, że założenia tych koncepcji wymagają ważnych dostosowań do specyfiki rynku turystycznego (Żemła, 2010). Na podstawie przeglądu ujęć wizerunku w literaturze marketingowej Szromnik (2007) wskazuje na sześć pojęć, za pomocą których wizerunek może być definiowany (rycina 1).

Rycina 1. Pojęcia, za pomocą których definiowany może być wizerunek miejsca
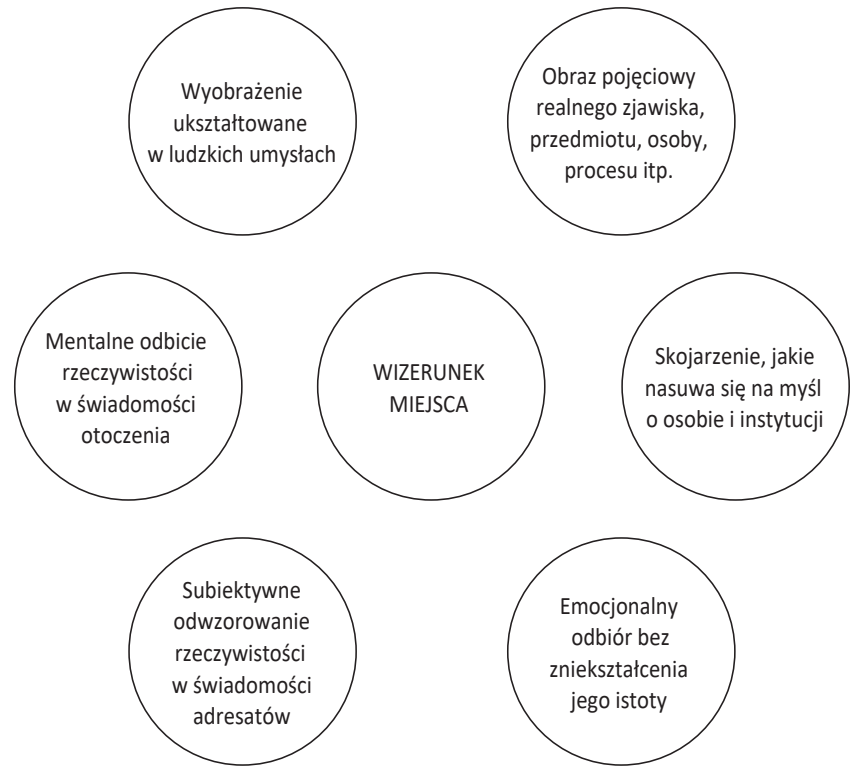

Źródło: opracowanie własne na podstawie Szromnik (2007: 133) 
Wielu autorów (Gartner, 1994; Souiden, Ladhari, Chiadmi, 2017; Stylidis et al., 2020; Woosnam et al., 2020) wskazuje na istnienie trzech podstawowych wymiarów wizerunku destynacji turystycznej. Koncepcja ta wskazuje na potrzebę uwzględnienia czynników poznawczych (ang. cognitive image), emocjonalnych (ang. affective image) i behawioralnych (ang. conative image). Wizerunek poznawczy jest sumą tego, co turysta wie o danym miejscu, niezależnie od źródeł tej wiedzy. Obejmuje on świadomość, wiedzę i wyobrażenia na temat konkretnych cech i atrybutów destynacji. Dla formowania wizerunku kluczowe są także życzenia i obawy, nastawienie uczuciowe, przekonanie ludzkie, przez które „przefiltrowane” zostają odebrane obrazy i informacje (Olszewska, 2000; Woosnam, Stylidis, Ivkov, 2020). Wymiar emocjonalny wizerunku związany jest z indywidualnymi uczuciami, odczuciami, które budzi dany obiekt. Wreszcie elementy behawioralne odnoszą się do konkretnych zachowań poszczególnych turystów związanych z posiadanym wizerunkiem destynacji.

Liczni autorzy (Birdir S.S., Dalgic, Birdir, K., 2018; Kim, Chen, 2016; Kislali, Kavaratzis, Saren, 2016, 2020; Madden et al, 2016;) nawiązują w swoich opracowaniach do popularnej koncepcji C.A. Gunn (1972), rozwiniętej przez W.C. Gartnera (1994), wskazującej na dwa podstawowe składniki wizerunku: wizerunek organiczny i wizerunek indukowany. Podział ten w sposób bezpośredni odnosi się do procesu kształtowania wizerunku destynacji, jako że za główne kryterium różnicujące dwa elementy wizerunku przyjmuje się w nim źródło informacji i sposób ukształtowania (genezę). Wizerunek organiczny jest funkcją niekomercyjnych informacji uzyskiwanych przez potencjalnego turystę dzięki referencjom innych osób, własne doświadczenia i inne źródła niezależne od działań interesariuszy w ramach destynacji. Natomiast wizerunek indukowany jest wynikiem działań marketingowych, zwłaszcza promocyjnych podejmowanych przez marketerów w danym miejscu (Kim, Chen, 2016). Istotnym elementem uzupełniającym podział źródeł kształtowania wizerunku jest wskazanie na rolę samego odbiorcy przekazów (Madden et al., 2016; Tasci, Gartner, 2007). Zatem wizerunek destynacji składa się z elementów pochodzących od jednostki i elementów pochodzących z zewnątrz (Kislali, Kavaratzis, Saren, 2016; MacKay, Fesenmaier, 1997). Wyróżnione zostały trzy źródła czynników kształtujących wizerunek destynacji: sama destynacja, źródła autonomiczne (niezależne) i odbiorca. Wizerunków danej destynacji jest zatem tyle, ilu osobom na świecie jej nazwa nie jest obca (Dann, 1996). Z jednej strony przyczyną tego stanu rzeczy jest fakt, że trudno sobie wyobrazić sytuację, w której dwie osoby swoją wiedzę na temat danego miejsca czerpią z dokładnie identycznego zestawu informacji. Niemniej ważniejszą przyczyną różnicującą wizerunki destynacji u poszczególnych osób jest fakt, że na zestaw informacji docierających do danej osoby w procesie kształtowania wizerunku nakłada się charakterystyka psychospołeczna jednostki. Człowiek rejestruje pewne obiektywne informacje, które potem przetwarza. Jego podświadomość nadaje im znaczenia, wiąże te informacje i obrazy z jakimś mniej lub bardziej ostrym wyobrażeniem, a w efekcie powstaje konglomerat złożony z uczuć, sądów, opinii, postaw i faktów (Olszewska, 2000). Tak więc jak nie ma na świecie dwóch zupełnie identycznych (od strony psychospołecznej) osób, tak nie może być dwóch zupełnie identycznych wizerunków jednej destynacji.

Współczesne media elektroniczne, zwłaszcza social media, sprawiają, że tradycyjny podział na wizerunek indukowany i organiczny staje się mniej ostry, tak jak mniej ostra jest klasyfikacja przekazów w tych mediach na promocyjne i niepromocyjne (Garay 
Tamajón, Cànoves Valiente, 2017). Ponadto możliwość kontaktu z bardzo licznym gronem osób i wymiany prywatnych spostrzeżeń za pomocą przeznaczonych do tego platform (np. Trip Advisor) sprawiają, że współcześnie wzrasta znaczenie komponentu organicznego wizerunku, w tym tzw. marketingu szeptanego (ang. word of mouth - WOM) (Jalilvand, 2017; Kladou, Mavragani, 2015).

Koncepcja trzech źródeł kształtowania wizerunku pozwala szczególnie dokładnie ulokować i uzmysłowić znaczenie stereotypów dla budowy wizerunku destynacji. Według W. Lippmanna (1992), stereotyp to „umysłowy obraz rzeczywistości, uproszczony, niedokładny, wytworzony raczej nie w efekcie własnego doświadczenia, ale dzięki przekazowi społecznemu" (Lippmann, 1992; cyt. za: Michalczuk-Ouerghi, 2019). Stereotypy stanowią konstrukcje myślowe zakorzenione w języku i działające niczym „nieuświadomiony filtr”, przez który odbieramy to, co obce, inne i nieznane (Owsianowska, 2014). Stereotyp ma charakter uproszczonego i fragmentarycznego schematu wyróżniającego się połowiczną wiedzą i odpornością na zmiany (Nelson, 2003). Uproszczenia te mogą w określonych sytuacjach stanowić siłę wspierającą wybory przez potencjalnych turystów niektórych destynacji (Owsianowska, 2014), jednak w zdecydowanej większości przypadków stanowią inhibitory takich wyborów (Jankowski, Rzętała, 2007; Michalczuk-Ouerghi, 2019; Szubert, Żemła, 2019; Żemła, Szubert, 2019). A Jankowski i Rzętała (2007) oraz Szubert i Żemła (2019) na przykładzie miast Wyżyny Śląskiej pokazują, że w umacnianiu takich negatywnych stereotypów rolę mogą odgrywać nawet źródła informacji w swojej istocie neutralne i obiektywne, jak edukacja szkolna. W przypadku wizerunku destynacji turystycznej zachodzi zjawisko rzadkie na innych rynkach, polegające na fakcie, że potencjalni nabywcy znają nazwy (marki) bardzo wielu konkurujących ze sobą destynacji nie mając jednak osobistych doświadczeń z większością z nich. Ponadto wizerunek tych destynacji jest budowany w oparciu przede wszystkim o przekazy ze źródeł niezależnych od tych destynacji, takich jak edukacja szkolna, media, czy opinie znajomych. Zatem marketerzy projektujący kampanie kreowania wizerunku danego miejsca muszą zmierzyć się z faktem, że w umysłach wielu potencjalnych odbiorców miejsce to ma już pewien uproszczony obraz, który może się to wiązać z negatywnymi, bardzo mocno zakorzenionymi i trudnymi do zmiany za pomocą przekazów marketingowych, stereotypami.

\section{Nowa Huta - powstanie i rozwój dzielnicy a współczesne stereotypy}

Nowa Huta stanowiła jeden z największych w dziejach komunistycznej Polski projekt inżynierii społecznej. Na terenie jednej z podkrakowskich wsi 80 lat temu, 23 czerwca 1941 r., ruszyła budowa „idealnego miasta socjalistycznego” - Nowej Huty wraz z kombinatem metalurgicznym (Gądecki, 2013; Lebow, 2013). Nowa Huta w założeniach miała stanowić kontrast dla mieszczańskiego, tradycyjnego Krakowa, gdyż miała stanowić nowe, lojalne wobec władzy miasto robotnicze (Pozniak, 2014).

Od wielu lat Nowa Huta postrzegana jest przez socjologów jako fenomen społeczno-socjologiczny (Pozniak, 2014). Ludzie mieszkający w nowej dzielnicy tworzyli mieszankę kulturową. Powstanie kombinatu metalurgicznego - Huty im. Lenina - oraz miasta Nowa Huta stanowi przykład jednego z kierunków rozwoju, którym jest zlokalizowanie w jednym miejscu inwestycji przemysłowej oraz zupełnie nowego, dużego organizmu miejskiego (Lebow, 2013). 
Nowa Huta jest dzielnicą Krakowa, która niewątpliwie ma wiele walorów przyrodniczych i kulturowych, które są atrakcyjne turystycznie (Klaś, 2019). Występują w niej również takie elementy, które są swoistym nośnikiem historii, co dodatkowo stanowi o wyjątkowości tego miejsca. Niezaprzeczalnie materialne pozostałości socrealizmu stanowią współcześnie główne zasoby Nowej Huty. Nowa Huta miała być w zamyśle miastem idealnym, pierwszym w Polsce zaprojektowanym w stylu socrealistycznym. Główną cechą takiego stylu był monumentalizm i zwarta, koncentryczna zabudowa. Założono, że sercem Nowej Huty będzie plac Centralny, z którego miały wychodzić najważniejsze arterie miasta. Okolice placu Centralnego miały zapełnić się zwartą, monumentalną zabudową z elementami architektury z renesansu i baroku, wyrażonymi przez arkady, podcienia, duże okna, attyki, wystające gzymsy. W kierunku kombinatu zabudowa miała dzielić się na mniejsze, bardziej zaciszne osiedla. Zostały one pomyślane jako miasta-ogrody i jednostki sąsiedzkie, łączące usługi, urzędy, sklepy, ośrodki zdrowia oraz bazę przedszkolną i szkolną, co miało podnieść komfort życia mieszkańców.

Współczesna atrakcyjność Nowej Huty budowana jest wokół tego niepowtarzalnego mitu doskonałego miasta PRL-u, a istniejące dziedzictwo wzbogacane jest w obiekty współczesne wpisujące się w tę tematykę, takie jak działające w budynku dawnego kina Światowid Muzeum PRL (Klaś, 2019). Także krakowskie biura podróży w swoich ofertach wykorzystują skojarzenia Nowej Huty z minionym systemem społeczno-gospodarczym i organizują jednodniowe wycieczki „do PRL-u” dla osób odwiedzających Kraków. Niemniej jednak skojarzenia z PRL-em wywołują u licznych odwiedzających i u części mieszkańców Krakowa emocje negatywne, które zniechęcają do odwiedzenia dzielnicy (Radwan, 2017). Ponadto, istotna rozbieżność kulturowa między pozostałymi dzielnicami Krakowa a Nową Hutą powoduje, że wielu mieszkańców Krakowa do tej dzielnicy podchodzi z dużą rezerwą. Jednym z wyzwań, przed którymi stoi Nowa Huta obecnie, jest budowa pozytywnego wizerunku oraz uczynienie dzielnicy bardziej atrakcyjną (Radwan, 2017). Wizerunek Nowej Huty przez lata był przedstawiany przez pryzmat rozbojów i kradzieży, a tzw. czarne legendy o dzielnicy wpływały na wskaźnik jej popularności i prestiżu, ujawniający się np. w cenach mieszkań, które były znacząco niższe od cen nieruchomości w innych obszarach Krakowa (Golonka-Czajkowska, 2013). Według badań nad bezpieczeństwem w Krakowie, przeprowadzonych przez Instytut Socjologii Uniwersytetu Jagiellońskiego, w 2000 roku i osiem lat później mieszkańcy Krakowa uznawali Nową Hutę i Bieńczyce za najniebezpieczniejsze dzielnice miasta (Bezpieczeństwo w Krakowie..., 2020, 20 września). W 2015 r. najwięcej mieszkańców Krakowa (powyżej 80\%) oceniło pozytywnie bezpieczeństwo tylko w dzielnicach: Swoszowice, Bronowice i Zwierzyniec. Nowa Huta była przez nich postrzegana jako miejsce o średnim poziomie bezpieczeństwa. Mimo notowanej tam w ostatnich latach stosunkowo niskiej liczby przestępstw i wykroczeń, dzielnica nadal przez wiele osób - zarówno mieszkających w Krakowie, jak i odwiedzających miasto - jest uznawana za miejsce nieatrakcyjne i niebezpieczne (Radwan, 2017).

\section{Wyniki badań}

Problem badawczy niniejszego opracowania skupia się wokół zagadnień związanych z szeroko pojętą percepcją przestrzeni turystycznej. Celem artkułu jest przedstawienie postrzegania atrakcyjności turystycznej Nowej Huty przez osoby mieszkające na stałe 
bądź czasowo w Krakowie. Podstawę do realizacji tego celu stanowią przeprowadzone dla potrzeb pracy badania. W artykule postawiono następującą hipotezę badawczą: Występuje zróżnicowanie percepcji i postrzegania Nowej Huty w zależności od miejsca pochodzenia ankietowanych.

Do zweryfikowania hipotezy posłużyły pytania badawcze:

1. Z jakimi opiniami o Nowej Hucie spotkały się osoby uczestniczące w badaniu?

2. Jak postrzegają Nową Hutę ankietowani?

3. Jakie cechy można przypisać badanej dzielnicy?

Badania ankietowe na próbie 400 osób zamieszkujących na stałe lub czasowo w Krakowie przeprowadzone zostały w listopadzie 2019 za pomocą kwestionariusza umieszczonego w sieci Internet, do którego link przekazywany był metodą śnieżnej kuli. Poprawnie wypełnione kwestionariusze otrzymano od stałych mieszkańców Krakowa (39,8\%, w tym 14,3\% stanowili mieszkańcy Nowej Huty) i od osób zamieszkujących miasto czasowo (wśród nich 25,5\% byli to mieszkańcy miast, a 34,7\% - mieszkańcy wsi). Zdecydowana większość respondentów (99\% stałych mieszkańców i 83\% mieszkańców czasowych) była w Nowej Hucie, co sprawia, że ich opinie opierały się w znacznym stopniu także na własnych doświadczeniach, a nie tylko na przekazach ze źródeł zależnych i niezależnych.

Postrzeganie atrakcyjności Nowej Huty

W tabeli 1 przedstawiono opinie badanych na temat ogólnie pojętej atrakcyjności Nowej Huty. Ponad połowa respondentów uważała to miejsce za atrakcyjne. Największy odsetek dotyczył mieszkańców dzielnicy (96,5\%). Wśród mieszkańców Nowej Huty jedynie 1\% uważał to miejsce za nieciekawe, a kolejny $1 \%$ pozostał niezdecydowany.

Tabela 1. Percepcja Nowej Huty jako miejsca atrakcyjnego (\%)

\begin{tabular}{|l|c|c|c|}
\hline \multirow{2}{*}{ Miejsce zamieszkania } & \multicolumn{3}{|c|}{$\begin{array}{c}\text { Czy w Nowej Hucie } \\
\text { znajduje się coś ciekawego }\end{array}$} \\
\cline { 2 - 4 } & tak & nie & nie wiem \\
\hline Kraków & 60,78 & 25,49 & 13,73 \\
\hline Kraków-Nowa Huta & 96,49 & 1,75 & 1,75 \\
\hline Inne miasto & 50,98 & 11,76 & 37,25 \\
\hline Wieś & 53,96 & 17,99 & 28,06 \\
\hline Ogółem & 61,00 & 16,00 & 23,00 \\
\hline
\end{tabular}

Źródło: Opracowanie własne

Zbadane zostały także opinie, które, zdaniem respondentów, wyrażane są na temat Nowej Huty (tabela 2). Bezsprzecznie dominującą opinią o tej dzielnicy Krakowa jest przekonanie, iż jest ona niebezpieczna - aż 92,5\% odpowiedzi. Ponad połowa pytanych również spotkała się ze stwierdzeniem, że Nowa Huta „budzi strach”. Blisko połowa ankietowanych spotkała się z opiniami, że dzielnica ta jest szara (54\%), brzydka $(48,8 \%)$ i ponura (46\%). 40\% słyszało, że w tej części miasta jest brudno. Do pozytywnych opinii, których jest zdecydowanie mniej, można zaliczyć te, które mówią, że Nowa Huta jest ciekawa i interesująca (ok. 18\% ankietowanych) lub po prostu ładna (8,5\%). Opinie, 
z którymi spotykali się ankietowani, najczęściej miały charakter mieszany - opinie pozytywne przeplatały się z opiniami negatywnymi, jednak prawie trzykrotnie więcej osób spotkało się wyłącznie z negatywnymi opiniami w porównaniu z osobami, które słyszały tylko dobre rzeczy o tej dzielnicy. Wśród tych ostatnich dominowały osoby pochodzące lub na stałe zamieszkujące tę dzielnicę (ok. 10\%), zaś negatywne opinie przeważały u mieszkańców innych dzielnic Krakowa.

Tabela 2. Opinie o Nowej Hucie, z którymi spotkali się ankietowani

\begin{tabular}{|l|c|}
\hline \multicolumn{1}{|c|}{ Nowa Huta jest } & \% \\
\hline niebezpieczna & 92,50 \\
\hline budząca strach & 64,75 \\
\hline szara & 54,00 \\
\hline brzydka & 48,75 \\
\hline ponura & 46,04 \\
\hline brudna & 39,50 \\
\hline ciekawa & 18,50 \\
\hline interesująca & 17,75 \\
\hline ładna & 8,50 \\
\hline inne & 3,75 \\
\hline
\end{tabular}

Źródło: Opracowanie własne

Respondenci zostali także poproszeni o wyrażenie swojej opinii na temat ich percepcji Nowej Huty (tabela 3). Każdy z ankietowanych wskazywał, na ile zgadza się z prezentowaną opinią w skali pięciostopniowej, gdzie 1 oznacza "nie zgadzam się zupełnie”, a 5 - „zgadzam się całkowicie”. W tabeli 3 przedstawiono charakterystyki statystyczne uzyskanych odpowiedzi. Większość respondentów przychylała się do opinii takich jak ta, że Nowa Huta ma swój urok, że można tu znaleźć ciekawe miejsca, że ma potencjał turystyczny oraz że stanowi przyjazne miejsce (średnia 3,02-3,88). Opinie respondentów były podzielone mniej więcej po równo na temat tego, czy Nowa Huta jest miejscem brzydkim i bezpiecznym (średnia <3). Respondenci z Krakowa najczęściej uważali, że chociaż w Nowej Hucie można spotkać ciekawe miejsca $(37,3 \%)$ i ma ona swój urok $(21,6 \%)$, to jest ona miejscem stosunkowo niebezpiecznym, o niskim potencjale turystycznym (ok. 18\%). Zupełnie inaczej przedstawiała się sytuacja wśród mieszkańców Nowej Huty. Pozytywne opinie wyraziło $32-72 \%$ ankietowanych. Nieco ponad $47 \%$ całkowicie nie zgadzało się ze stwierdzeniem, że Nowa Huta jest brzydka. Około $70 \%$ ankietowanych uważało, że jest to dzielnica posiadająca ciekawe miejsca i swój urok. Ponad połowa mieszkańców (ok. 60\%) widziała w niej potencjał turystyczny, a co trzeci mieszkaniec twierdził, że jest ona miejscem bezpiecznym i przyjaznym.

W sposób szczególny należy zwrócić uwagę na wskazania mieszkańców Nowej Huty zdecydowanie odróżniające się od pozostałych odpowiedzi. We wszystkich pytaniach ich odpowiedzi zdecydowanie różniły się od odpowiedzi pozostałych grup i były to różnice także statystycznie istotne (p. 0,05). W każdym przypadku też opinie mieszkańców były bardziej przychylne Nowej Hucie. 
Tabela 3. Percepcja Nowej Huty przez respondentów

\begin{tabular}{|c|c|c|c|c|}
\hline $\begin{array}{c}\text { Miejsce } \\
\text { zamieszkania }\end{array}$ & Średnia & Minimum & Maksimum & $\begin{array}{l}\text { Istotność różnic } \\
\text { w porównaniu } \\
\text { z odpowiedziami } \\
\text { mieszkańców } \\
\text { Nowej Huty (p) }\end{array}$ \\
\hline \multicolumn{5}{|c|}{ Nowa Huta ma swój urok } \\
\hline Kraków & 3,32 & 1,00 & 5,00 & 0,001 \\
\hline $\begin{array}{l}\text { Kraków-Nowa } \\
\text { Huta }\end{array}$ & 4,63 & 3,00 & 5,00 & - \\
\hline Inne miasto & 3,46 & 1,00 & 5,00 & 0,001 \\
\hline Wieś & 3,32 & 1,00 & 5,00 & 0,001 \\
\hline Ogółem & 3,54 & 1,00 & 5,00 & - \\
\hline \multicolumn{5}{|c|}{ W Nowej Hucie jest bezpiecznie } \\
\hline Kraków & 2,72 & 1,00 & 4,00 & 0,005 \\
\hline $\begin{array}{l}\text { Kraków-Nowa } \\
\text { Huta }\end{array}$ & 3,89 & 2,00 & 5,00 & - \\
\hline Inne miasto & 2,90 & 1,00 & 5,00 & 0,008 \\
\hline Wieś & 2,83 & 1,00 & 5,00 & 0,007 \\
\hline Ogółem & 2,97 & 1,00 & 5,00 & - \\
\hline \multicolumn{5}{|c|}{ Nowa Huta jest brzydka } \\
\hline Kraków & 2,77 & 1,00 & 5,00 & 0,001 \\
\hline $\begin{array}{l}\text { Kraków-Nowa } \\
\text { Huta }\end{array}$ & 1,86 & 1,00 & 4,00 & - \\
\hline Inne miasto & 2,81 & 1,00 & 5,00 & 0,004 \\
\hline Wieś & 2,87 & 1,00 & 5,00 & 0,012 \\
\hline Ogółem & 2,69 & 1,00 & 5,00 & - \\
\hline \multicolumn{5}{|c|}{ W Nowej Hucie można znaleźć ciekawe miejsca } \\
\hline Kraków & 3,72 & 1,00 & 5,00 & 0,001 \\
\hline $\begin{array}{l}\text { Kraków-Nowa } \\
\text { Huta }\end{array}$ & 4,70 & 3,00 & 5,00 & - \\
\hline Inne miasto & 3,87 & 1,00 & 5,00 & 0,004 \\
\hline Wieś & 3,67 & 1,00 & 5,00 & 0,001 \\
\hline Ogółem & 3,88 & 1,00 & 5,00 & - \\
\hline \multicolumn{5}{|c|}{ Nowa Huta ma potencjał turystyczny } \\
\hline Kraków & 3,12 & 1,00 & 5,00 & 0,002 \\
\hline $\begin{array}{l}\text { Kraków-Nowa } \\
\text { Huta }\end{array}$ & 4,47 & 2,00 & 5,00 & - \\
\hline Inne miasto & 3,13 & 1,00 & 5,00 & 0,001 \\
\hline Wieś & 3,19 & 1,00 & 5,00 & 0,001 \\
\hline Ogółem & 3,34 & 1,00 & 5,00 & - \\
\hline \multicolumn{5}{|c|}{ Nowa Huta jest miejscem przyjaznym } \\
\hline Kraków & 2,77 & 1,00 & 5,00 & 0,001 \\
\hline $\begin{array}{l}\text { Kraków-Nowa } \\
\text { Huta }\end{array}$ & 4,12 & 2,00 & 5,00 & - \\
\hline Inne miasto & 2,89 & 1,00 & 5,00 & 0,005 \\
\hline Wieś & 2,83 & 1,00 & 5,00 & 0,009 \\
\hline Ogółem & 3,02 & 1,00 & 5,00 & - \\
\hline
\end{tabular}

Źródło: Opracowanie własne 


\section{Dyskusja i wnioski}

Nowa Huta jest dzielnicą, której społeczny, subiektywny obraz od bardzo dawna obciążony jest wieloma stereotypami wyrosłymi na gruncie uwarunkowań historycznych. Powstał obraz miasta-fabryki, dymiących kominów, biednej klasy robotniczej, brudnej i zaniedbanej dzielnicy. Wyobrażenie to na tyle zakorzeniło się w powtarzanych stereotypach, mimo że rzeczywistość od stereotypów różni się istotnie, co potwierdzają m.in. opinie mieszkańców dzielnicy. Aby zweryfikować powszechność zakorzenionych opinii i wyobrażeń, w badaniach postawiono pytania dotyczące opinii na temat Nowej Huty, z którymi spotkali się respondenci. Zaskakujące jest to, że aż ponad 90\% respondentów spotkało się z opinią, że Nowa Huta jest dzielnicą niebezpieczną. Drugim najczęściej wskazywanym przekonaniem było to, że dzielnica ta budzi strach. Jest to o tyle ciekawe, że współcześnie opinia ta zdecydowanie mija się z prawdą.

Wielu respondentów pochodzących $\mathrm{z}$ innych dzielnic Krakowa lub innych miast spotkało się z opinią, że Nowa Huta jest brudna i brzydka. Może to wynikać z faktu, że w dużych miastach powstają nowoczesne biurowce i osiedla, których wygląd jest przeciwieństwem architektury Nowej Huty, zaplanowanej w sposób kompleksowy, co nie sprzyja modyfikacji planów przestrzennych dzielnicy. Ponadto pod koniec 2020 r. weszła w życie uchwała o utworzeniu Parku Kulturowego w Nowej Hucie. Jego powstanie pozwoli chronić unikalny układ urbanistyczny i wyjątkową architekturę w najstarszej części dzielnicy. Podobnie, w roku 2019, indywidualnym wpisem do rejestru zabytków Krakowa zostały objęte budynki administracyjne nowohuckiego kombinatu, co zabezpieczy obiekt przed integracją w elewację lub wymianą wyposażenia wnętrz prowadzącą do zmiany charakteru budynku. Ankietowani często spotykali się też z opiniami, że Nowa Huta jest szara i ponura. Może to wiązać się z niewielkimi nakładami na odnowę elewacji bloków osiedlowych, które w większości są koloru szarego, zwłaszcza w okolicach głównej atrakcji dzielnicy, którą jest plac Centralny. Do mało popularnych opinii można zaliczyć te, które wskazywały na pozytywne cechy dzielnicy. Jedną z nich było przekonanie, iż Nowa Huta jest ładna. Częściej pojawiały się opinie, że jest ona interesująca lub ciekawa.

Wyniki badań pokazują, że opinie mieszkańców Nowej Huty wyraźnie odbiegają od opinii pozostałych ankietowanych. Stanowi to potwierdzenie hipotezy badawczej postawionej na wstępie. Opinie mieszkańców Nowej Huty mają charakter zdecydowanie bardziej korzystny. Jest to pozytywna obserwacja, świadcząca o utożsamianiu się z tym miejscem oraz o tym, że mieszkańcy Nowej Huty są czynnymi obserwatorami zmian, które zachodziły na przestrzeni lat i nadal trwają.

Analiza wizerunku Nowej Huty prowadzi do wniosków oryginalnych, ale i trudnych do praktycznego wykorzystania. $Z$ reguły bowiem kreowanie wizerunku destynacji turystycznych, czy też innych obszarów, odbywa się w ramach granic administracyjnych i możliwe jest wskazanie odpowiedzialnych za to władz publicznych. W przypadku Nowej Huty mamy do czynienia $\mathrm{z}$ dzielnicą miasta, a więc obszarem pozbawionym reprezentacji samorządowej z szerokimi uprawnieniami. Odpowiedzialność za kreowanie wizerunku Nowej Huty spada zatem na władze miasta Krakowa. Jednak w tym przypadku naturalnym, najważniejszym zadaniem będzie dbanie o wizerunek miasta jako całości. Pozostawia to Nową Hutę na uboczu działań zmierzających do doskonalenia wizerunku, podejmowanych przez władze lokalne, gdyż dzielnica ta ma swoją bardzo silną tożsamość, która nie wpisuje się w tożsamość miasta jako całości. Sytuacja ta nie tylko nie sprzyja 
ograniczaniu wpływu negatywnych stereotypów, ale także utrudnia wykorzystanie bardzo silnej tożsamości Nowej Huty do budowy pozytywnego przekazu. Nowa Huta, dzięki swojej specyfice i silnej tożsamości, posiada istotny potencjał rozwoju funkcji turystycznej i rekreacyjnej, który obecnie pozostaje w znacznej części niewykorzystany.

W dalszych badaniach tematu warto szerzej rozwinąć kwestię pozytywnych skojarzeń, które mogą być stosunkowo łatwo łączone z dzielnicą. Konieczne wydaje się także poszukiwanie rozwiązań organizacyjnych w innych miastach Europy i świata, które pozwoliłyby na udaną rewitalizację wizerunku pojedynczej dzielnicy. Otwarta pozostaje też kwestia drogi tej rewitalizacji. Obecnie możliwe wydają się obie drogi wskazywane w literaturze: próba budowy nowego wizerunku w oderwaniu od obecnie dominujących skojarzeń oraz wykorzystanie tych skojarzeń i próba naddania im pozytywnego wydźwięku, budowy wokół nich pozytywnych emocji (Szubert, Żemła, 2019).

Bardzo ważnym wynikiem przeprowadzonych badań jest też wskazanie różnicy między postrzeganiem Nowej Huty przez mieszkańców dzielnicy a postrzeganiem jej przez inne osoby. Z jednej strony jest to potwierdzenie zasady obserwowanej wielokrotnie w badaniach, mówiącej, że osobista znajomość miejsca wpływa na ograniczenie wpływu stereotypów, co przekłada się na bardziej pozytywne jego postrzeganie. Z drugiej strony, istotna zaobserwowana różnica sugeruje, że pozytywne emocje, które wzbudza w mieszkańcach ich dzielnica, stanowią ogromny potencjał przyszłego kreowania wizerunku tego miejsca. W wielu miejscach obarczonych powszechnym i stereotypowym wyobrażeniem problemem jest też brak pozytywnej percepcji ze strony ich mieszkańców. W przypadku Nowej Huty, w świetle wyników badań, ten problem nie powinien mieć miejsca.

\section{Literatura}

References

Afshardoost, M., Eshaghi, M.S. (2020). Destination image and tourist behavioural intentions: A meta-analysis. Tourism Management, 81, 104-154.

Bezpieczeństwo w Krakowie. Raport z badań. (2020, 20 września). Pozyskano z: https://www.google. $\mathrm{com} / \mathrm{url}$ ? $\mathrm{sa}=\mathrm{t} \& \mathrm{rct}=\mathrm{j} \& \mathrm{q}=\& \mathrm{esrc}=\mathrm{s} \&$ source $=$ web $\& \mathrm{~cd}=\& \mathrm{ved}=2 \mathrm{ahUKEwjF7NTPyerzAhXvpIsKH}-$ QU1D9kQFnoECAMQAQ\&url=https\%3A\%2F\%2Fwww.bip.krakow.pl\%2Fzalaczniki\%2Fdokumenty\%2F21826\&usg=AOvVaw3yovMixaUCFYbii-mGvR75

Birdir, S.S., Dalgic, A., Birdir, K. (2018). Destination marketing and destination image. In: D. Gursoy, C.G. Chi (eds.), The Routledge handbook of destination marketing (71-81). New York: Routledge.

Crompton, J.L. (1979). An assessment of the image of Mexico as a vacation destination and the influence of geographical location upon that image. Journal of Travel Research, 17(4), 18-23.

Dann, G.M. (1996). Tourists' images of a destination-an alternative analysis. Journal of Travel \& Tourism Marketing, 5(1-2), 41-55.

Garay Tamajón, L., Cànoves Valiente, G. (2017). Barcelona seen through the eyes of TripAdvisor: Actors, typologies and components of destination image in social media platforms. Current Issues in Tourism, 20(1), 33-37.

Gartner, W.C. (1994). Image formation process. Journal of Travel \& Tourism Marketing, 2(2-3), 191216.

Gądecki, J. (2013). Odkrywając miasto idealne? Marginalna gentryfikacja starej części dzielnicy Nowa Huta. Studia Regionalne i Lokalne, 14(54), 64-81.

Go, F.M., Govers, R. (2000). Integrated quality management for tourist destinations: a European perspective on achieving competitiveness. Tourism Management, 21(1), 79-88. 
Golonka-Czajkowska, M. (2013). Nowe miasto nowych ludzi: mitologie nowohuckie. Kraków: Wydawnictwo Uniwersytetu Jagiellońskiego.

Gunn, C.A. (1988). Vacationscape: Designing tourist regions. Van Nostrand Reinhold.

Jankowski, A.T., Rzętała, M. (2007). Stereotyp w postrzeganiu stanu środowiska przyrodniczego Wyżyny Śląskiej. W: K. Ostaszewska (red.), Znaczenie badań krajobrazowych dla zrównoważonego rozwoju. Uniwersytet Warszawski. Warszawa: Wydział Geografii i Studiów Regionalnych UW, 641-654.

Jalilvand, M.R. (2017). Word-of-mouth vs. mass media: Their contributions to destination image formation. Anatolia, 28(2), 151-162.

Kim, H., Chen, J.S. (2016). Destination image formation process: A holistic model. Journal of Vacation Marketing, 22(2), 154-166.

Kim, S., Lehto, X., Kandampully, J. (2019). The role of familiarity in consumer destination image formation. Tourism Review, 74(4), 885-901.

Kislali, H., Kavaratzis, M., Saren, M. (2016). Rethinking destination image formation. International Journal of Culture, Tourism and Hospitality Research, 10(1), 70-80.

Kislali, H., Kavaratzis, M., Saren, M. (2020). Destination image formation: Towards a holistic approach. International Journal of Tourism Research, 22(2), 266-276.

Kladou, S., Mavragani, E. (2015). Assessing destination image: An online marketing approach and the case of TripAdvisor. Journal of Destination Marketing \& Management, 4(3), 187-193.

Klaś, J. (2019). Nowa Huta na szlakach kulturowych. Turystyka Kulturowa, 3, 92-114.

Lebow, K., (2013). Unfinished Utopia. New York: Cornell University Press.

Li, J.J., Ali, F., Kim, W.G. (2015). Reexamination of the role of destination image in tourism: an updated literature review. E-review of Tourism Research, 12, 191-209.

MacKay, K.J., Fesenmaier, D.R. (1997). Pictorial element of destination in image formation. Annals of Tourism Research, 24(3), 537-565.

Madden, K., Rashid, B., Zainol, N.A. (2016). Beyond the motivation theory of destination image. Tourism and Hospitality Management, 22(2), 247-264.

Michalczuk-Ouerghi, K. (2019). Wpływ stereotypów narodowych na wybór destynacji turystycznejprzykład Tunezji. Czasopismo Geograficzne, 90(1), 60-74.

Nelson, T.D. (2003). Psychologia uprzedzeń. Gdańsk: Wydawnictwo Psychologiczne.

Olszewska, J. (2000). Wizerunek jako narzędzie tworzenia przewagi strategicznej gminy. Marketing i Rynek, 11, 24-37.

Owsianowska, S. (2014). Stereotypy w narracji turystycznej. Turystyka Kulturowa, 3, 6-20.

Pozniak, K. (2014). Nowa Huta: Generations of change in a model socialist town. Pittsburgh: University of Pittsburgh Press.

Radwan, A. (2017). Wyzwania w zarządzaniu rozwojem miasta na przykładzie dzielnicy Nowa Huta. Zarzadzanie Publiczne, 37(1), 81-90.

Smith, S.L. (1994). The tourism product. Annals of Tourism Research, 21(3), 582-595.

Souiden, N., Ladhari, R., Chiadmi, N.E. (2017). Destination personality and destination image. Journal of Hospitality and Tourism Management, 32, 54-70.

Stylidis, D., Woosnam, K.M., Ivkov, M., Kim, S.S. (2020). Destination loyalty explained through place attachment, destination familiarity and destination image. International Journal of Tourism Research, 22(5), 604-616.

Szromnik, A. (2015). Strategia city placement w systemie innowacji marketingowych. Cz. 1. Marketing i Rynek, 8, 5-14.

Szromnik, A. (2007). Marketing terytorialny. Miasto i region na rynku. Warszawa: Wolters Kluwer Polska.

Szubert, M., Żemła, M. (2019). The Role of the Geographical Textbooks in Grounding Negative Stereotypes of a Tourism Destination - The Case of Upper Silesian Conurbation in Poland. Administrative Sciences, 9(2), 42. 
Tasci, A.D., Gartner, W.C. (2007). Destination image and its functional relationships. Journal of Travel Research, 45(4), 413-425.

Woosnam, K.M., Stylidis, D., Ivkov, M. (2020). Explaining conative destination image through cognitive and affective destination image and emotional solidarity with residents. Journal of Sustainable Tourism, 28(6), 917-935.

Żemła, M. (2010). Wartość dla klienta w procesie kształtowania konkurencyjności obszaru recepcji turystycznej. Katowice: Wydawnictwo Górnośląskiej Wyższej Szkoły Handlowej im. Wojciecha Korfantego.

Żemła, M. (2003). Podstawy formułowania strategii kształtowania produktu turystycznego regionu. Katowice: Wydawnictwo Górnośląskiej Wyższej Szkoły Handlowej im. Wojciecha Korfantego.

Żemła, M., Szubert, M. (2019). Wizerunek miast konurbacji górnośląskiej - wyzwanie przełamywania stereotypów. Annales Universitatis Paedagogicae Cracoviensis Studia Geographica, 13, 57-77.

Michał Żemła, dr hab., prof. uczelni, Uniwersytet Pedagogiczny im. Komisji Edukacji Narodowej w Krakowie, Instytut Geografii, Katedra Turystyki i Badań Regionalnych. Autor licznych publikacji związanych z marketingiem i konkurencyjnością produktu turystycznego obszaru. Przedmiotem jego szczególnego zainteresowania jest rozwój turystyki na obszarach górskich, zwłaszcza ośrodków narciarskich i turystyki pieszej.

Michał Żemła, PhD, associate professor, Pedagogical University of Krakow, Institute of Geography, Department of Tourism and Regional Studies. The author of numerous publications on destination's product marketing and competitiveness. The subject of his main interest is development of tourism in mountain areas with special emphasis on winter sports and hiking tourism.

ORCID: https://orcid.org/0000-0002-3521-8128

\section{Adres/Address:}

Uniwersytet Pedagogiczny im. Komisji Edukacji Narodowej w Krakowie

Instytut Geografii

ul. Podchorążych 2

30-084 Kraków, Poland

e-mail: michal.zemla@up.krakow.pl

Rafał Woronkowicz, student studiów magisterskich na kierunku turystyka i rekreacja na Uniwersytecie Pedagogicznym im. Komisji Edukacji Narodowej w Krakowie. Do zainteresowań badawczych autora należą percepcja oraz postrzeganie społeczne różnych destynacji turystycznych wraz z ich wpływem na uwarunkowania i rozwój ruchu turystycznego, a także wpływ stereotypów na rozwój turystyki na danym obszarze recepcyjnym.

Rafał Woronkowicz, MA student of Tourism and Leisure at the Pedagogical University of Krakow. The author's research interests include perception and social perception of various tourist destinations along with their impact on the conditions and development of tourist traffic. He also deals with the impact of stereotypes on the development of tourism in particular destinations.

ORCID: https://orcid.org/0000-0001-5108-2892

\section{Adres/Address:}

Uniwersytet Pedagogiczny im. Komisji Edukacji Narodowej w Krakowie

Instytut Geografii

ul. Podchorążych 2

30-084 Kraków, Poland

e-mail: woronkowicz.rafal@gmail.com 